\title{
Impact de la sécheresse à Pampas-la florida (1976-1980) : comportements et stratégies paysannes
}

Isabelle Lausent-Herrera

\section{(2) OpenEdition}

Journals

Édition électronique

URL : https://journals.openedition.org/tc/907

DOI : $10.4000 /$ tc. 907

ISSN : 1952-420X

Éditeur

Éditions de l'EHESS

Édition imprimée

Date de publication : 1 septembre 1986

ISSN : 0248-6016

Référence électronique

Isabelle Lausent-Herrera, «Impact de la sécheresse à Pampas-la florida (1976-1980) : comportements et stratégies paysannes », Techniques \& Culture [En ligne], 7 | 1986, mis en ligne le 23 janvier 2006, consulté le 29 septembre 2022. URL : http://journals.openedition.org/tc/907 ; DOI : https://doi.org/ $10.4000 /$ tc. 907

Ce document a été généré automatiquement le 29 septembre 2022

Tous droits réservés 
Impact de la sécheresse à Pampas-la florida (1976-1980) : comportements et stratégies paysannes

Isabelle Lausent-Herrera 